\title{
Thoughts on the Dormitory Interpersonal Relationship of Countryside Undergraduate
}

\author{
Wenna Chen \\ North China Electric Power University,Baoding, Hebei071000,China \\ 1250025087@qq.com
}

\begin{abstract}
Keywords: the university enrollment expansion, dormitory massacre, dormitory interpersonal relationship, characteristics, reasons, suggestions
\end{abstract}

\begin{abstract}
Influenced by our country adoptingthe policy of university enrollment expansion since 1999 , the quantity of college students has been rising year after year. Countrysidealso skewed by the policy, to some extent makes a larger number of impoverished students have the opportunity to stepped into the threshold of the colleges and universities.But rural college students, in recent years, due to the dormitory interpersonal relationship problems, have caused the tragedy not beingin theminority. Based on the university dormitory massacre as the breakthrough point, and combined with the author's own experiences of growing up to analysethe characteristics of the rural students' ways of treatingothers as well as doing things, this paper, then, willstudy the causes of the formation of those characteristics, finally uniting themselves among the reasons for the rural students, in healthy personality to put forward some feasible Suggestions.
\end{abstract}

\section{Introduction}

Referring to the college students from the countryside, rural college students this group, before 1999, extremely rare, must haveexperienced unbearable pain that the ordinary failed to bear. Yet in the university enrollment expansion, the rural students canget into university, both specialized subject and undergraduate course, even as they all work less harder than those before 1999. The education system in colleges and universities expansion came along with the resulting despite promoting the role of the education fair chance, but many universities as well occasionally broke out the awful massacre caused by improper handlingdormitory relationship between rural students and their roommates. ${ }^{[1-3]}$ Tow convincing illustrations occuring to me go to Jiajue Ma who murdered four lives related to his roommates in February, 2004, and Shijie Zeng having killed one besides hurting two at 9:10 or so,on the evening of30th, March, 2010. Both theycame from countryside. These killings are so gruesome that society had to put the focus to college students originally to accumulate knowledge in the pure school. How come they are growingevillyso as to waveButcher's knife to their elbow roommates? Although these extreme eventshave not appeared, in many colleges and universities, but behind it, dormitory interpersonal relationship problems, is the real problem each colleges and universities have to face. The existing literature on ordinary college students' dormitory relations have been discussed much more detailed, so the purpose of this paper is to analyse the rural students in the treatment of the related problem in dormitory relations.

\section{The characteristics of the rural students' ways of treating others as well as doing things}

I was admitted to a "211 universities" in 2013 , the first to afamous university in the rural family.On the first day of entering university, however, I felt the different states of the same kind of person:being in a room,others were accompanied by parents and can buy anything they want, but I do need to save money for my familyso that I had no extra money to buy a bottle of iced drinks in hot summer.While in junior high school, I was the top student of the class, in the university, just discovered myself so poor, afraid to speak in class, dare not to talk aloud to roommates and to speak to the teacher in eye contract.Under the quality education in China, some kind of learning tasks are easy for other college students in the city, but for me, really awesome to do.I felt pretty unhappy 
and that was what I showed myself to others. Therefore, my roommates all dare not play jokes on me in our freshman days, instead told me, "You don't smile as if you were angry", for which I can only be explained I was born to be like this, not truelyangry. Whenever I said something,only if roommates remained silent, did I assume that I must have done somethingwrong, telling myself to speek less later.Sometimes, I got very depressed, feeling how hard I tried, still couldn't achieve what I pursued. Inner decadent aspect can be showed in everything in a glance.

Rural college students have an inferiority complex heart, tending to become "three can't" while coming across something. ${ }^{[3]}$ When it comes to the rural students' personality, a lot of people maight think of low self esteem which is usually reflected under the following circumstances. In class, the university teacher requests the classmates speak enthusiastically. Rural college studentss can't rise their hands highly, tending to put their hands on the chest in a complexed mood, wandering either speaking orgiving up. In the dormitory, when disagreeing with roommates, they can't state their own point of view, afraid to upset roommates. After class, they can 'tconsult the teacher on some misunderstanding questions, afraid to offendteacher by their own inappropriatewords. This is so-called "three can ' $t$ " phenomenon caused by inferiority mentality. The more one can't, the more one feel inferior, and the more roomates dislike him(or her), in a vicious cycle.

Rural college students have a sensitive heart, seizing the small "drill horn".Rural children from an early age knew the difficulty in the home, usually a more sensible child knew forparents share and others, to a certain extent, this is a kind of very good quality. Yet there are also many rural college students as the university campus lifeis very different than those in the past, will actas ifDaiyuLinentering Jia Fu"always keep an eye on everything". Dormitory memberstend to be in a lot of small disagreement and friction. When rural oneasks for roommates help, they may not notice one's requestat that time, but the one would regard roommates are not willing to help her(or him). In turn, the rural individuals will seek for reason by themself. Having found out so-called causes in their own world,they then changetheir sociable way: the enlightened would owe the reason to themselves and swear not to seek roommates` help; the lessenlightened would never considerate others any more; the least enlightened would bear a grudge in mind and revengeroommates at a crucial time.

Rural college students have a heart of glass, suffering injustice to"sigh fate". Rural college students on the state of mind often can't afford to lose: when suffering injustice at ordinary times ,they are more likely to go to extremes, and so there were mentioned many university dormitory murders in the former context. Heart of glass is used to describing the person who is easy to be hurt. The sdutents from countryside have to overcome many barriers than those from city. The first is the problem of ecnomy. Many rural college students work many part-time jobs to supplement the daily expenses. The second is the limited ability with which they can 't deal with thechallenging task assigned by teachers. The last but not least is the barrier about communication. Under the suppression of multiple barriers, if they don't get ideal results, rural college students are easy to cause frustration, believingthat ten times the effort is also less than half of the others. The most intuitionistic comparison derives from the dormitory, and contradictions will be produced in the dormitory.

\section{The reasons for such characteristics.}

Above all is Chinese rural college students' common shortcomingson the characterand behavior. Some behavior can be considered as normal reaction, but some is great enough to make incredible things.

The enrollment expansion of colleges introduced class contradictions into the campus life. Frankly speeking, University enrollment expansion was toto boost domestic demand and strengen economic growth, objectively seeming to have played an important role inpromoting education fair. But what is clear to everyone is the fact that a growing number of rural students admitted tocolleges and universities is not because of their own ability and literacy enough to adapt to the demanding university life, but more opportunity.Therefore, the two obvious classes - -students from 
countryside and ones from city-- came into being, and it is palpable to imagine thecontradictionagainst the background of two totally different groups in the same dorm.

The effect onideological moral education is not obvious.In system of the teaching, it is seriously detrimental to improve the quality of the classin a big classroom with a large number of students.From the student perspective, it is tougher and tougher for them to concentrate on what contentthe teacher is giving. To make matters worse, many student attend this class merely not to be caught when the teacher call theroll. In addition to those, the teacher should also reflect on their teaching ability.Therefore, the ideological moral education of colleges almost become a mere formality in helping college students set up the correct outlook on life, values and world view.

The rural college students are not good at communication, with whom the urban college students are reluctant to communicate. ${ }^{[4]}$ Communication is the bridge of understanding, if the two groups are not active to communicate with each other ,the understanding is impossible to go on.Harmonious dormitorywill on the small things in life help one another during the day and talking freely before sleeping at night. Unfortunately, however, in many dormitories, memberscome and go freelyduring the day, absorbed in mobile phone at night.

The economic gap widens the gap of dormitory interpersonal. ${ }^{[5]}$ There are often six or four people in onecollege dorm, coexisting one room of people from all over the country, against different background, but the biggest influence on dormitory relations is the economic factor. Rural college students are generally poorer, consideringdoing part-time job in their spare time. Yet the urban students have conditions to travel around. So, communication beteewn rural college students and their roommates usually stop from learning daily affairs, less chance of activities together in the life. The widening economic gap inevitably enlarge rural college students and their dormitory roommateswhose economic conditions are better off.

\section{To the rural students' suggestions}

The author offersthe following Suggestions for the rural students ' dealing with the relationship in the dormitory and living a better university life.

Set up the consciousness of " business before pleasure". When your roommates get better grades than yourself, not envying, what you really need to do is figuring out the reasons. Perhaps, the biggest problem lies in your deeds, which you pay much attention to pleasure before. There a saying goes "It's easier said than done". Setting up the consciousness of "business before pleasure"will look at the achievements of others correctelyand motivate yourselfbetter.

Dare to trust roommates. Rural students away from home, without friends, can put the roommates as their loved ones and open up to tell the roommates everything.Everyone's heart is made of meat, when the other party harveststhe trust from his(or her)rural roomates, trusting in return, so that the friendship can be built up byunderstanding and trust and any misunderstandings can be resolved in a timely manner.

Read more to change the pattern of the ego.${ }^{[6]}$ Reading more books makes a person beautiful.Though rural college students have no economic power to be dressed up in appearance, but they can derive the nutrition from the book. This requires rural college students arrange time to read books, not to blindly work part-time.A personal spiritual rich is the real rich.

Be kind to make progress together .Rural college students should be calm in the face of the interests war in the university, treating it with the common heart, only with the endorsement of roommates, can the interest make sense.If not, you are still a looser. So, just be kind to your roommates, learning to win support from them, even if you don't get your way bacause of their stronger power. After all, you grow up and own a sound personality which is more important than anything else.

\section{Acknowledgment}

${ }^{1}$ Jiajue Ma, Baidu encyclopedia http : // baike. baidu. Com / link ?url = ZI Gaen 9Ba 8qk 4qo NL Bi R 867u 210Y 1xN MSe2oxW Kr 8JDWXInHqtUMNethPEE8iVSh9iIs zzMp-_jhsL-zBKt7cq 
${ }^{1}$ Shijie Zeng, Baidu encyclopedia http : // baike .baidu .com /link ? url = rtjQ t9DiS bXBjg 2mwCLFVBmvoFwAhB9HKvjnygfd9vXbzkv8CFJ2klLcrYDk61SB3_3eBQuahQjBXm89Xie7rq

${ }^{1}$ Xueqin Cao, Chapter Three in the Dream of Red Mansions

${ }^{1}$ University enrollment expansion, Good search, http : //baike .haosou .com/ doc/ 47498 4-4965195. html

\section{Reference}

[1] XiaoMaXiao. Rural self-abased psychology of university students and beyond, J. Science of social psychology, $2004: 110-113$.

[2] Xiaocheng Yin. Introduction to college students how to build a harmonious dormitory relations ,J. Science wenhui (ten-day), $2012:$ 190-191.

[3] Yanhua Wu. Rural poverty university students "psychological weakness" causes and effects and countermeasures analysis ,D. [to an unknown] : fujian normal university, 2007.

[4]YeLixia. Shallow discuss reasons and countermeasures of college students' dormitory relations ,J. Journal of nanchang institute of education, 2012: 74-75.

[5] Wu Qingyun. Rural college students' consumption psychology and behavior analyses ,J. Journal of assets and financial administration career, $2014: 114$.

[6] Jiang Libo. The current situation of the poor female college students' dormitory interpersonal relationship and the adjustment countermeasures ,J. Journal of union BBS (journal of union management cadre institute in shandong province), 2010,: 90-91. 